\title{
Abradeosporangium, a new genus of Mucorales (Fungi: Zygomycetes) from India
}

\author{
A. Subrahmanyam ${ }^{1}$, A. Swathi Sri ${ }^{2} \&$ Vatsavaya S. Raju ${ }^{3}$ \\ 1,2 Department of Biotechnology, Meerut Institute of Engineering and Technology, NH 58, Baghpat Bypass Cross, Meerut, \\ Uttar Pradesh, 250005, India \\ ${ }^{3}$ Plant Systematics Laboratory, Department of Botany, Kakatiya University, Warangal, Andhra Pradesh 506009, India \\ Email: ${ }^{1}$ mycothermal@yahoo.co.in; ${ }^{3}$ satyavatsa@yahoo.co.in (corresponding author)
}

\begin{abstract}
Abradeosporangium, a new genus of Mucorales with its type species $A$. variosporum, is described from India. The new genus is distinct in producing dimorphic sporangia and multispored, acolumellate and globose macrosporangia with persistent, thin peridium. Sparingly, portions of the sporangial wall at the top and bottom of the sporangia are dissolved at maturity to release the sporangiospores whilst, in its close ally Gilbertella, the sporangium breaks open via a longitudinal suture. Further, the smaller sporangia (microsporangia) are without a longitudinal suture and produce variable number of spores. The sporangiospores are pale brown, longitudinally striated without any appendages. Besides, the new genus produces neither rhizoids nor zygospores.
\end{abstract}

Keywords: Abradeosporangium, Mucorales, Mycota, new genus, Zygomycetes.

During the course of exploration of fungi of Meerut district, Uttar Pradesh, India, an interesting isolate bearing dimorphic sporangia on distinct sporangiophores was discovered from the rat excreta and decomposing Hibiscus flowers gathered from the campus of Meerut

Date of publication (online): 26 September 2010

Date of publication (print): 26 September 2010

ISSN $0974-7907$ (online) | 0974-7893 (print)

Editor: V.B. Hosagoudar

Manuscript details:

Ms \# 02374

Received 28 December 2009

Final revised received 18 March 2010

Finally accepted 28 July 2010

Citation: Subrahmanyam, A., A.S. Sri \& V.S. Raju (2010) Abradeosporangium, a new genus of Mucorales (Fungi: Zygomycetes) from India. Journal of Threatened Taxa 2(10): 1219-1222.

Copyright: () A. Subrahmanyam, A. Swathi Sri \& Vatsavaya S. Raju 2010. Creative Commons Attribution 3.0 Unported License. JoTT allows unrestricted use of this article in any medium for non-profit purposes, reproduction and distribution by providing adequate credit to the authors and the source of publication.

Acknowledgements: The authors thank Dr. V.B. Hosagoudar (Senior Scientist, TBGRI, Thiruvananthapuram, India), for going through the manuscript and the help with the Latin diagnosis. Thanks are due to Sri Vishnu Saran, Chairman and Prof. V.N. Sharma, Director, Biotechnology, MIET, for laboratory facilities, Sri Shariq lqbal for assistance in photography and Sri Sachin Kumar for typing the script.

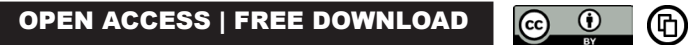

Institute of Engineering and Technology (MIET). Some of the macrosporangia dehisce along a longitudinal suture as in Blakeslea and Gilbertella (Binny 1991). However, the present isolate differs from both these genera in several diagnostic characters. Hence, it is warranted to accommodate the present isolate in a new genus of Mucorales.

\section{Abradeosporangium Subrahm. et A. Swathi Sri, gen. nov. \\ (Mucorales, Zygomycetes) (Image 1; Figs. 1-5)}

Material examined: Holotype: 08.x.2008, Anamorph, soil and decomposing Hibiscus flowers, MIET Campus, Meerut, India, coll. A. Swathi Sri (MIET Culture Bank: Fungi 126) (MycoBank \# 518785).

Sporangia dimorpha; macrosporangia globosa, atrobrunnea, columella nulla, multispora, parietus tenues, ad apicem et basim dissolutus ad maturitatus et sporae liberatus, aliquot sporangia dehisce longitudinalis. Microsporangia plus minus globosa, dilutus brunnea, multisporata, parietus glabrus, persistens et sutura longitudinalis nulla. Sporangiosporae globosae, variabilis, dilute brunneae vel brunneae, striatus longitudinalis minutus, plerumque ovalis, sporae globosae, raro fucus et dumbelliformes. Zygosporae nullae.

Sporangia dimorphic; macrosporangia globose, dark brown, acolumellate, multispored with smooth, thin-walled (peridium) which at maturity dissolves at the top and bottom to release the spores. Some of the sporangia split open along the longitudinal suture as in Blakeslea (Ho \& Chang 2003) and Gilbertella (Hesseltine 1960; Mehrotra \& Mehrotra 1963). Microsporangia nearly globose, pale brown, with variable number of sporangiospores; peridium smooth, persistent and without any longitudinal suture. Sporangiospores variable in shape, pale brown to brown, finely longitudinally striated, usually oval or globose, occasionally fusiform to dumbbell shaped. Zygospores absent.

Etymology: The generic name refers to breakage or dissolution of sporangium; L: abrādō: damage; sporangium.

Type species: Abradeosporangium variosporum, sp. nov. 

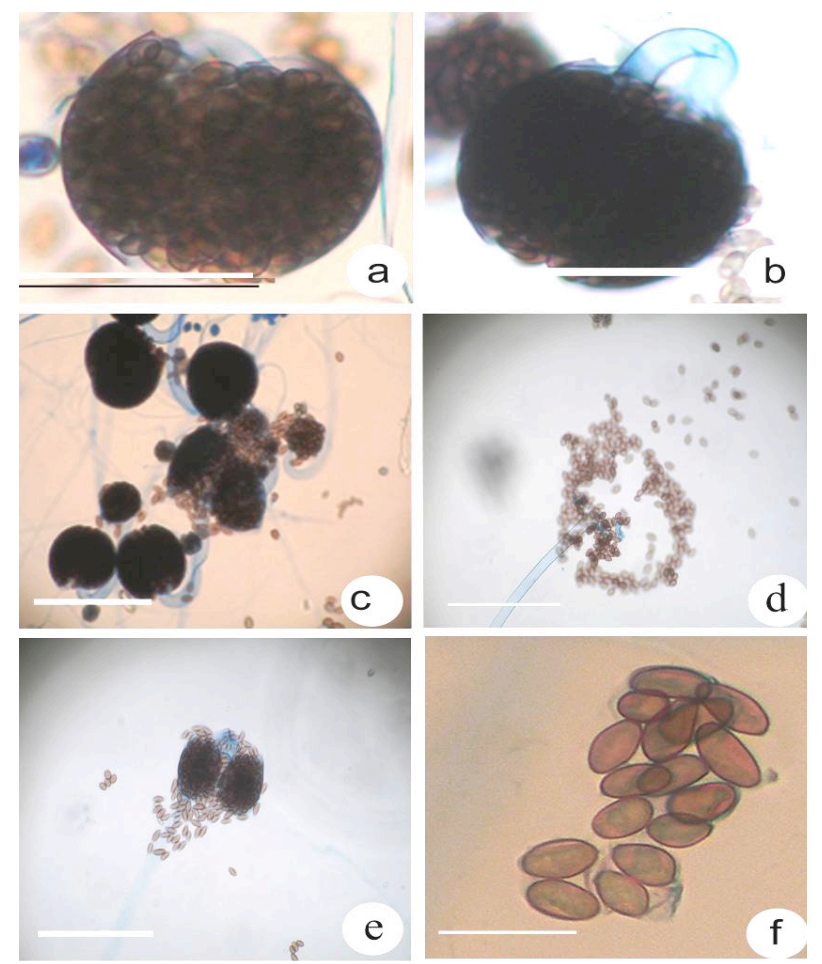

Image 1. Abradeosporangium variosporum gen. et sp. nov. a, b-Mature macrosporangia with goose-necked sporangiophores; c - Macro- and microsporangia;

$\mathrm{d}$ - Distal part of sporangiophore after dehiscence of the macrosporangium, without columella;

e - Macrosporangium dehisced along the longitudinal suture; $\mathrm{f}$ - Sporangiospores without appendages.

\section{Abradeosporangium variosporum Subrahm. et A. Swathi Sri, sp. nov. (Image 1; Figs. 1-5)}

Mycelium aseptatus, hyalinus, glabrus, ramosus; sporangiophorae hyalinae, lateralis, non-ramosus, aseptatae, statim inferne sporangiorum curvatae, producentes sporangia ad terminalis; sporangia dimorpha, producentes sporangiophores separatis. Macrosporangia magna, spherica, atrobrunnea, acolumellata, multispora, 101-109 $\mu \mathrm{m}$ diam.; parietus sporangiorum hyalinus, glabrus, persistentes; parietus inferne et ad apicem dissolutus et sporangiosporae liberatae; saepe sporangia dehiscentes longitudinalis. Microsporangia numerosa, producentes pedicellae lateraliter, dilute brunneae, sutura longitudinalis nulla, 12-42 $\mu \mathrm{m}$ diam.; sporangiosporae dilute brunneae vel brunneae, appendices nullae, striatus longitudinalis minutae, plerumque ovoideae, 7-10 x3-5 $\mu$ m, sporae globosae, ad 10 $\mathrm{mm}$ diam., saepe dumbelliformes velfusiformes; chlamydosporaeintercalares veltermilnalis, glabrae, cylindraceae, solitariae, dilute brunneae, 6-8 $x$ 1-2 $\mu m$; zygosporae nullae.

Mycelium aseptate, hyaline, smooth, branched; sporangiophores hyaline, lateral, unbranched, aseptate and curved proximate to the sporangium even at maturity, bear a single sporangium distally; sporangia dimorphic, born on separate sporangiophores. Macrosporangia large, spherical, dark brown, acolumellate, multispored, 101-109 $\mu \mathrm{m}$ in diam.; peridium smooth, persistent; but

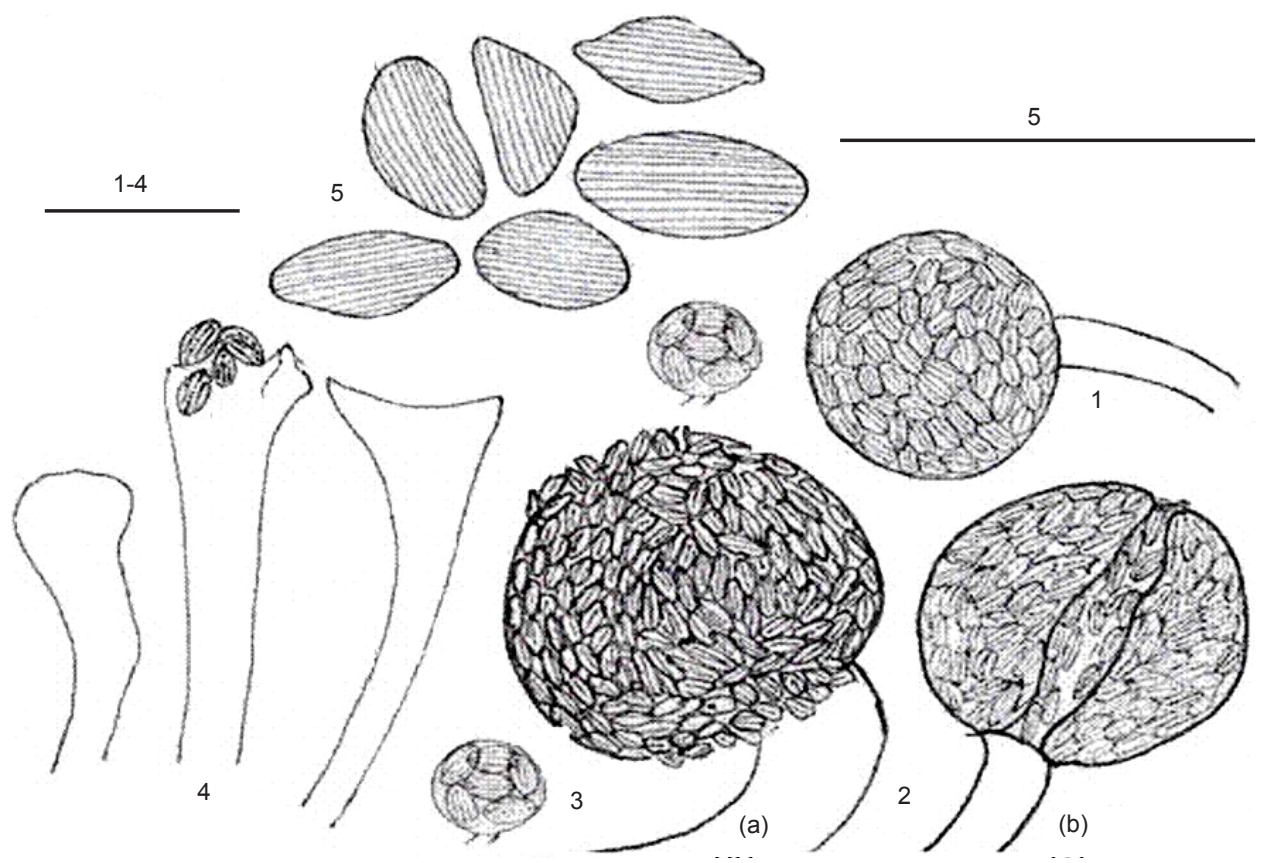

Figure 1-5. Abradeosporangium variosporum gen. et sp. nov.

1 - Macrosporangium (10 x 40X); 2 - Mature sporangia showing (a) dissolution of sporangial wall; (b) breaking of sporangial wall along the longitudinal suture $(10 \times 40 X) ; 3$ - Microsporangia $(10 \times 40 X) ; 4$ - Distal parts of sporangiophores after the dispersal of spores $(10 \times 40 \mathrm{X})$, note the absence of columella; 5 - Sporangiospores $(10 \times 40 \mathrm{X})$. 
Table 1. Comparison of diagnostic characters of Blakeslea, Gilbertella and Abradeosporangium gen. nov.

\begin{tabular}{|c|c|c|c|}
\hline Taxon & $\begin{array}{l}\text { Blakeslea Thaxt., } 1914 \\
\text { (B. monospora B.S. } \\
\text { Mehrotra \& Baijal, 1968) }\end{array}$ & $\begin{array}{l}\text { Gilbertella Hesselt., } 1960 \\
\text { (G. persicaria (E.D. Eddy) } \\
\text { Hesselt., 1960) }\end{array}$ & $\begin{array}{l}\text { Abradeosporangium Subrahm. et A. Swathi Sri, } \\
\text { gen. nov. (A. variosporum Subrahm. et A. Swathi } \\
\text { Sri, sp. nov.) }\end{array}$ \\
\hline Sporangiophores & $\begin{array}{l}\text { Erect, ascending, branched, } \\
\text { irregularly constricted. }\end{array}$ & $\begin{array}{l}\text { Simple, rarely branched; } \\
\text { curved immediately below the } \\
\text { sporangium but straightens at } \\
\text { maturity. }\end{array}$ & Simple, goose-necked even at maturity. \\
\hline Macrosporangia & $\begin{array}{l}\text { Globose, yellowish-brown to black, } \\
\text { multispored, } 45-170 \mu \mathrm{m} \text {; wall } \\
\text { persistent covered with crystalline } \\
\text { spines; breaks into two equal halves } \\
\text { through a longitudinal suture with a } \\
\text { drop of sporangial content. }\end{array}$ & As in Blakeslea monosperma. & $\begin{array}{l}\text { Globose, dark brown, multispored, thin-walled, } \\
\text { smooth. In some sporangia, part of the wall } \\
\text { at top and bottom get dissolved to release } \\
\text { sporangiospores. In others, the sporangium } \\
\text { breaks along a longitudinal suture as in } \\
\text { Gilbertella or Blakeslea but without a droplet of } \\
\text { sporangial contents. }\end{array}$ \\
\hline Microsporangia & $\begin{array}{l}\text { 1-8 spored, borne on barrel-shaped } \\
\text { pedicles that cover the globose } \\
\text { vesicles; open by a longitudinal } \\
\text { suture. }\end{array}$ & None. & $\begin{array}{l}\text { Present on simple short stalks; longitudinal } \\
\text { suture absent; bear variable number of spores. }\end{array}$ \\
\hline Columella & Present. & Present. & Absent. \\
\hline Sporangiospores & $\begin{array}{l}\text { Fusiform, pigmented, striate and } \\
\text { bear a group of long, fine, hyaline } \\
\text { appendages at each pole. }\end{array}$ & $\begin{array}{l}\text { Globose, broadly fusiform or } \\
\text { ellipsoid to ovoid or irregular } \\
7.6-11.4 \times 6.4-8.9 \mu \mathrm{m} \text {, } \\
\text { smooth; bear long, slender } \\
\text { appendages at the poles. }\end{array}$ & $\begin{array}{l}\text { Pale brown to brown, finely striated, oval, } 7-10 \\
\times 3-5 \mu \mathrm{m} \text {, globose, } 10 \mu \mathrm{m} \text { dumbbell or spindle- } \\
\text { shaped spores occasionally formed; } \\
\text { appendages absent at the poles. }\end{array}$ \\
\hline Chlamydospores & & $\begin{array}{l}\text { Ovoid, doliform, cylindrical or } \\
\text { irregular, } 11.32 \times 10-16 \mu \mathrm{m} \text {, } \\
\text { light brown, smooth. }\end{array}$ & $\begin{array}{l}\text { Oval, barrel-shaped, single, intercalary, pale } \\
\text { brown, smooth, } 6-8 \times 2 \mu \mathrm{m} \text {. }\end{array}$ \\
\hline $\begin{array}{l}\text { Zygospores } \\
\text { (telomorph) }\end{array}$ & Present. & Present. & Absent. \\
\hline
\end{tabular}

(After Thaxter 1914; Hesseltine 1960; Mehrotra \& Baijal 1968; Kirk 1984; Benny 1991; present study)

at maturity, part of the wall at the top and bottom gets dissolved to release the sporangiospores; a few sporangia split open along the longitudinal suture as in Blakeslea and Gilbertella (Table 1). Microsporangia numerous, born on small lateral stalks, pale brown with variable number of spores without longitudinal suture, $12-42 \mu \mathrm{m}$ in diam.; sporangiospores lack appendages, pale brown to brown, smooth, finely longitudinally striated, shape variable, most commonly ovoid, $7-10 \times 3-5 \mu \mathrm{m}$ or globose, up to $10 \mu \mathrm{m}$ in diam., occasionally dumbbell or fusiform shaped spores also formed; chlamydospores intercalary or terminal; smooth, barrel-shaped, single, pale brown, 6-8 x 1-2 $\mu \mathrm{m}$; zygospores absent.

Culture characterization: The fungus grows on most of the common media like potato dextrose agar, $2 \%$ malt extract agar, oatmeal agar, YpSs agar and also on synthetic mucor agar.

(i) On oatmeal agar: Growth profuse; colonies at room temperature white to pale yellow, fast growing, cover $80 \mathrm{~mm}$ plate in $72 \mathrm{~h}$. Aerial mycelium well-developed, appear granular with the development of sporangia; sporangia pale brown, turn black on maturation. Sporulation characteristically begins from periphery of the colony; reverse colony colourless; diffusible pigment absent.

(ii) On potato dextrose agar: Growth profuse; colonies at room temperature fast growing, cover $80 \mathrm{~mm}$ plate in 72h. Mycelium dull-white, raised, zonate, crest and trough-like with depressed area at the centre. Sporulation characteristically begins from periphery of the colony in the aerial mycelium. It appears granular with the initiation of pale brown sporangia which turn black on maturation; reverse colony pale woody yellow; sporulation abundant.

On almost all media, the mycelial growth is zonate, crest-like and trough type; sporulation always begins from the periphery of the colony.

\section{Discussion}

Abradeosporangium gen. nov. is a saprophytic mucoralian genus producing acolumellate dimorphic sporangia. On most of the mycological media, it produces crest and trough type growth. Sporulation characteristically begins from the periphery of the colony. It produces multispored, psilate macrosporangia. The sporangiophores are goose-necked even at maturity (dehiscence time). The release of sporangiospores is either through a longitudinal suture as in Gilbertella and Blakeslea, or by dissolving a part of the sporangial wall (peridium) at the top and bottom. The latter trait makes Abradeosporangium gen. nov. distinct. While Gilbertella and Blakeslea produce columellate sporangia (Table 1), the sporangia are acolumellate in the present isolate (Image 1; Fig. 1). 
Furthermore, the microsporangia, unlike Blakeslea (Kirk 1984), are produced distally on simple sporangiophores and not on barrel-shaped pedicles covering the surface of globose vesicles. The suture present in the microsporangial wall of Blakeslea is wanted in Abradeosprongium gen. nov. Moreover, the sporangiospores are simple, longitudinally striated, ovoid or globose and do not bear hyaline appendages at the poles as in Blakeslea and Gilbertella. Besides, zygospores and rhizoids are wanted. Another interesting feature of the present isolate is that it fails to sporulate on slants.

Other distinct features of the new genus: Growth on most of the media is characteristically crest and trough type; sporulation always begins from the periphery of the colony. It sporulates freely in a plate but not in a tube. Several combinations like PDA $+2 \%$ cow dung extract; soil extract + SMA agar; soil extract + cow dung extract, PDA + SMA - all of them incubated at $18^{\circ}, 24^{\circ}, 28^{\circ}$ and $37^{\circ}$ $\mathrm{C}$ but sporulation could not be induced in tube culture.

\section{REFERENCES}

Benny, G.L. (1991). Gilbertellaceae, a new family of Mucorales (Zygomycetes). Mycologia 83: 150-157.

Hesseltine, C.W. (1960). Gilbertella gen. nov. (Mucorales). Bulletin of Torrey Botanical Club 87: 21-30.

Ho, H.-M. \& L.-L. Chang (2003). Notes on Zygomycetes of Taiwan (III): Two Blakeslea species new to Taiwan. Taiwania 48: 232-238.

Kirk, P.M. (1984). A monograph of Choanephoraceae. Mycological Papers 152: 1- 61.

Mehrotra, B.S. \& M.D. Mehrotra (1963). A morphological and physiological study of Gilbertella in India. Mycologia 55: 582594.

Mehrotra, B.S. \& U. Baijal (1968). Is Blakeslea a valid genus? Journal of Elisha Mitchell Science Society 84: 207-210.

Thaxter, R. (1914). New or peculiar Zygomycetes. 3. Blakeslea, Dissophora and Haplosporangium, nova genera. Botanical Gazette 58: 353-366. 